\title{
Contribution of forest foods to dietary intake and their association with household food insecurity: a cross-sectional study in women from rural Cameroon
}

\author{
Robert Fungo ${ }^{1,2, *}$, John Muyonga ${ }^{1}$, Margaret Kabahenda ${ }^{1}$, Archileo Kaaya ${ }^{1}$, \\ Clement A Okia ${ }^{3}$, Pauline Donn ${ }^{4}$, Tchatat Mathurin ${ }^{5}$, Obadia Tchingsabe ${ }^{5}$, \\ Julius C Tiegehungo ${ }^{2}$, Judy Loo ${ }^{2}$ and Laura Snook ${ }^{2}$ \\ ${ }^{1}$ School of Food Technology, Nutrition \& Bio-Engineering, Makerere University, PO Box 7062, Kampala, Uganda: \\ ${ }^{2}$ Bioversity International Forest Genetic Resources Programme, Via dei Tre Denari, Rome, Italy: ${ }^{3}$ World Agroforestry \\ Centre (ICRAF), Uganda Country Office, Kampala, Uganda: ${ }^{4}$ National School of Agro-Industrial Science, Agro-food \\ Processing, University of Ngaoundéré, Ngaoundéré, Cameroon: ${ }^{5}$ Institut de Recherche Agricole pour le \\ Développement, Yaoundé, Cameroon
}

Submitted 23 June 2015: Final revision received 16 April 2016: Accepted 3 May 2016: First published online 6 June 2016

\begin{abstract}
Objective: To determine the contribution of forest foods to dietary intake and estimate their association with household food insecurity.

Design: Cross-sectional survey conducted among 279 households. Using a $7 \mathrm{~d}$ recall questionnaire, information on household food consumption was collected from women and used to determine the household dietary diversity score, food variety score and forest food consumption score (FFCS). Household Food Insecurity Access Scale (HFIAS) score was determined and Spearman rank correlation was used to establish the relationship between consumption of forest foods and HFIAS score. Women's dietary intake was estimated from two $24 \mathrm{~h}$ recalls. The contribution of forest foods to women's nutrient intakes was calculated and women's nutrient intakes were compared with estimated average nutrient requirements.

Setting: Rural forest-dependent households in twelve villages in eastern and southern Cameroon.

Subjects: Household heads and their non-pregnant, non-lactating spouses.

Results: Forty-seven unique forest foods were identified; of these, seventeen were consumed by $98 \%$ of respondents over the course of one week and by $17 \%$ of women during the two $24 \mathrm{~h}$ recall periods. Although forest foods contributed approximately half of women's total daily energy intake, considerably greater contributions were made to vitamin A (93\%), Na (100\%), Fe (85\%), Zn (88\%) and $\mathrm{Ca}(89 \%)$ intakes. Despite a highly biodiverse pool of foods, most households (83\%) suffered from high food insecurity based on the HFIAS. A significant inverse correlation was observed between the HFIAS score and the FFCS $\left(r^{2}=-0 \cdot 169\right.$, $P=0 \cdot 0006$ ), demonstrating that forest foods play an important role in ensuring food security in these forest-dependent communities.

Conclusions: Forest foods are widely consumed by forest-dependent communities. Given their rich nutrient content, they have potential to contribute to food and nutrition security.
\end{abstract}

\author{
Keywords \\ Biodiversity \\ Dietary diversity \\ Nutrient intake and forest foods
}

Sub-Saharan Africa, with close to 214 million undernourished people, remains the world's most food-insecure region $^{(1)}$. However, Africa has a highly biodiverse environment, with valuable, but often neglected and underutilized resources such as foods obtained from forest species $^{(2)}$. Cameroon is endowed with a rich biodiversity, represented by about 9000 plant species and over forty threatened animal species ${ }^{(3)}$. However, low quality and monotonous diets dominate the daily meals of Cameroonians, raising the risk of undernutrition ${ }^{(1,4)}$. The supply of starchy staples in Cameroon and the rest of Africa is largely dependent on a small number of cultivated and imported species and varieties ${ }^{(1,5,6)}$. A diet that is not diversified may result in negative consequences on an 
individual's well-being and development, as this kind of diet may not meet essential nutrient requirements ${ }^{(7,8)}$. Studies indicate that assessing the intake of traditional, wild or forest foods could successfully reveal how the consumption of locally available foods is related to the well-being of communities ${ }^{(8)}$. Despite the underutilization and neglect of forest foods, studies indicate that these foods can enrich household diets, providing essential nutrients and bioactive compounds that can prevent undernutrition and coronary diseases, and provide sources of income for millions of people ${ }^{(1,9-15)}$. These foods also act as a safety net during times of shortage of other foods ${ }^{(16)}$. Income-generating forest foods such as Gnetum africanum (African wild vegetable) and Irvingia gabonensis (bush mango) in Cameroon and Nigeria are being protected and domesticated, thus increasing on-farm agrobiodiversity while contributing to greater dietary diversity and improved access to essential nutrient components in an otherwise monotonous and nutritionally poor diet ${ }^{(5,17-19)}$.

Undernutrition is a widespread problem in Cameroon despite some improvements ${ }^{(18)}$. During the last 15 years, the prevalence of stunting in Cameroonian children below 5 years of age has declined from 36 to $33 \%$ and the proportion of underweight children has declined from 18 to $15 \%$. Despite the decline, the current prevalences of stunting and underweight in Cameroon are unacceptably high $^{(20,21)}$. The prevalence of wasting among children below 5 years in this country worsened from 5\% in 1991 to $6 \%$ in $2011^{(20,21)}$. It is estimated that if measures are not taken to reduce undernutrition, affected individuals will experience a $10 \%$ loss of lifetime earnings and developing countries such as Cameroon will suffer a 3\% annual reduction in gross domestic product ${ }^{(22)}$.

Current interventions to control undernutrition in Cameroon include vitamin and mineral supplementation and provision of nutrition education to mothers during the prenatal period ${ }^{(23)}$. However, these interventions are provided to relatively few accessible, rural forestdependent communities ${ }^{(24)}$. Complementing the existing interventions with food-based strategies such as nutrition education coupled with the promotion of sustainable utilization of forest foods can be a feasible strategy to address undernutrition ${ }^{(25)}$. However, detailed studies describing the contribution of forest foods to nutrient intakes and food security among forest-dependent communities of Cameroon are scarce. This has led to a routine undervaluation of forest foods in diets and their neglect by researchers, policy makers and nutritionists ${ }^{(26)}$. The present study aimed to assess the contribution of forest foods to the nutrient intakes of women, as well as to evaluate the association between the consumption of these foods and household food insecurity. This information can support the formulation of policies and programmes related to utilization of these foods in Cameroon.

\section{Methodology}

\section{Characteristics of study sites}

Cameroon is located in the humid forest zone of the Congo Basin region, a hotspot of biodiversity ${ }^{(27)}$. The study was conducted in the eastern and southern regions of Cameroon (see online supplementary material, Supplemental Fig. 1). These regions have a long rainy season that lasts between May and November ${ }^{(27)}$. The two study sites can be accessed using asphalted roads over $150 \mathrm{~km}$ from Yaoundé city. The study villages in each study site can be reached only by forest tracks.

\section{Study population}

The population around the eastern site is about 25783 , composed mainly of the Kako, Pol and Baka pygmy ethnic groups, living in forty-one villages ${ }^{(28)}$. The population in the southern site is estimated to be 79353 ; all are of the Bulu ethnic group, living in twenty-nine villages ${ }^{(29)}$. The population in the southern region comprises mainly peasant farmers who grow both food and cash crops for export to Gabon and Equatorial Guinea ${ }^{(28)}$. The populations in the eastern region are predominantly hunters and gatherers of wild foods, with some sections of the population engaged in the commercial farming of plantain ${ }^{(29)}$.

\section{Study design, village and bousebold selection}

A two-stage cluster sampling technique involving one stage of purposeful selection and one stage of random selection was deployed in the selection of the study villages. In the first stage, districts within each site were purposefully selected on the basis of their accessibility and ethnicity. In the second stage, villages were randomly selected within the chosen districts. In the eastern site, the study was conducted in six villages, namely Kouedjina, Kagnol 3, Ndembo, Petit Pol, Melambo, Nkolbikon and Bonando; while in the southern site the study was conducted in five villages, namely Ngon, Bissam, Ondondo, Methyikpwale and Meyos.

The sample size was derived using Fisher's ${ }^{(30)}$ formula: $n=\left[t^{2} \times p(1-p)\right] / m^{2}$, where $n=$ required sample size, $t=$ confidence level at $95 \%$ (standard value of 1.96), $p=$ estimated proportion of the population directly depending on the forest for food $(9.9 \%)^{(31)}$ and $m=$ margin of error at $5 \%$ (standard value of 0.05 ). The calculation resulted in a total of 276 households to be interviewed in the two sites. To cater for attrition during the data collection process, the number of households per site was increased by $5 \%$, totalling 303 households. This sample size was about $40 \%$ of the total number of households in each village and representative of the population in the study area. With the help of the village authorities, mapping and listing of households in each village were done to obtain village lists for random selection. Households were randomly selected from each village list. A total of 279 
households in the two sites were selected, resulting into a response rate of $92 \%$.

\section{Data collection}

\section{Interviews}

Enumerator-administered interviews were used to collect data on sociodemographic characteristics and food consumption from non-pregnant and non-lactating women older than 18 years, who were married or cohabiting. The study focused on interviewing women because in rural African settings women are responsible for food collection and preparation and are custodians of knowledge on forest foods, that is passed on from generation to generation $^{(32)}$. Pregnant and lactating women were excluded from the sample as their energy and nutrient needs are different from those of other adults ${ }^{(33)}$. Interviews took place in the respondents' homes during the month of May 2012. The long rainy season in Cameroon commences in May and ends in November ${ }^{(27)}$. All questionnaires and tools were pre-tested and adapted to the local context.

\section{Housebold characteristics}

The interviews solicited information on the age, gender, economic occupation, education level of the head of household, materials used to construct the household dwelling and household food insecurity (Table 1).

\section{Forest food knowledge and species identification}

Focus group respondents were asked which forest plant species they consumed, which parts of each species and in what form. Forest food species were identified in the field with the help of local informants using Cameroonian vernacular plant names ${ }^{(24,34)}$. Plant specimens were photographed, collected and taken to the Yaoundé I University herbarium to be identified by an ecologist. A total of forty-seven forest food species were documented (see online supplementary material, Supplemental Table 1). The species names were also verified using the International Plant Names Index website (www.ipni.org) and classified into botanical families according to the APGII system as proposed by Termote et $a l .^{(12)}$.

\section{Dietary assessment and nutrient intakes}

Quantitative assessment of nutrient intakes was conducted using two $24 \mathrm{~h}$ recalls, with each recall conducted in the space of one week. Crude means of the two recalls were used for analysis. The two $24 \mathrm{~h}$ recalls allowed minimizing of intra-individual intake variation. Overestimated intakes in one of the recall days were evaluated according to the Goldberg cut-off method ${ }^{(35)}$ and none were excluded. Emphasis was placed on extracting as much information as possible from women because in rural African settings women prepare household meals, so they have a memory of foods and can estimate portion sizes ${ }^{(36)}$. The $24 \mathrm{~h}$ recall was validated based on previous studies conducted in
Table 1 Sociodemographic characteristics of households in southern and eastern Cameroon in May 2012

\begin{tabular}{|c|c|c|}
\hline Household characteristic & $n$ & $\%$ \\
\hline Age of household head (years) & 277 & \\
\hline Mean & & $43 \cdot 7$ \\
\hline Minimum & & $17 \cdot 0$ \\
\hline Maximum & & $82 \cdot 0$ \\
\hline Education of household head & 277 & \\
\hline No formal education & & $4 \cdot 7$ \\
\hline Primary class $1-4$ & & $21 \cdot 3$ \\
\hline Completed primary school & & $42 \cdot 2$ \\
\hline Failed to complete Form 4 & & $22 \cdot 0$ \\
\hline Completed secondary Form 4 & & $6 \cdot 9$ \\
\hline Completed secondary Form 6 & & $1 \cdot 1$ \\
\hline Completed Form $4+$ vocational training & & $1 \cdot 1$ \\
\hline Completed university & & 0.7 \\
\hline Household size group & 258 & \\
\hline Low $(1-4)$ & & 33.7 \\
\hline Medium (5-9) & & $56 \cdot 2$ \\
\hline High $(10-14)$ & & $10 \cdot 1$ \\
\hline Residence within the study area & 275 & \\
\hline$<12$ months & & $2 \cdot 2$ \\
\hline $1-2$ years & & $3 \cdot 6$ \\
\hline$>2-<5$ years & & $7 \cdot 3$ \\
\hline$>5-<10$ years & & $6 \cdot 2$ \\
\hline$>10$ years & & 80.7 \\
\hline Residence before coming into the study area & 277 & \\
\hline Same area (outskirts of forest) & & $75 \cdot 1$ \\
\hline Another forest (not current forest site) & & $13 \cdot 0$ \\
\hline Another part of this forest & & 8.7 \\
\hline Inside the forest & & 3.2 \\
\hline Energy source for cooking & 276 & \\
\hline Firewood & & $97 \cdot 2$ \\
\hline Charcoal & & $2 \cdot 2$ \\
\hline Paraffin stove & & 0.8 \\
\hline Source of energy for lighting & 277 & \\
\hline Kitchen firewood & & $66 \cdot 9$ \\
\hline Electricity & & $30 \cdot 0$ \\
\hline Paraffin lantern & & 3.3 \\
\hline Water source & 276 & \\
\hline Pond & & $62 \cdot 0$ \\
\hline River & & $17 \cdot 0$ \\
\hline Public spring & & 10.5 \\
\hline Bore hole & & $9 \cdot 1$ \\
\hline Piped & & 1.6 \\
\hline $\begin{array}{l}\text { Economic activities of forest-dependent } \\
\text { communities }\end{array}$ & 279 & \\
\hline Farming & & $51 \cdot 8$ \\
\hline Hunting and gathering forest foods & & 28.0 \\
\hline Trading & & $7 \cdot 6$ \\
\hline Artisan works & & $5 \cdot 3$ \\
\hline Salaried employment & & $3 \cdot 2$ \\
\hline Artisanal logging \& informal timber trading & & $2 \cdot 9$ \\
\hline Pension & & $11 \cdot 0$ \\
\hline Casual employment & & 0.4 \\
\hline HFIAS $\dagger$ & 279 & \\
\hline Food secure & & $16 \cdot 8$ \\
\hline Mildly food insecure & & $47 \cdot 0$ \\
\hline Moderately food insecure & & 7.5 \\
\hline Severely food insecure & & 28.7 \\
\hline
\end{tabular}

Data presented are number of households and percentage of the total number of households.

tHousehold Food Insecurity Access Scale; total score (range 0-27) is calculated from the individual scores of the nine frequency-of-occurrence questions and categorized into four levels of household food insecurity.

Cameroon ${ }^{(37-39)}$. A list was recorded of meals, dishes, food items and beverages consumed in the last $24 \mathrm{~h}$. Respondents were asked for a full description of ingredients in mixed dishes and amounts eaten were estimated using household 
measures and models. Respondents were also prompted for specific foods such as snacks and drinks. Portion sizes were estimated using a variety of different local utensils to help the respondents in estimating the quantities of foods or ingredients consumed $^{(40)}$. In addition, two digital scales (Soehnle, Nassau, Germany; precision $10 \mathrm{~g}$ ) were used to estimate weights of corresponding utensil volumes and leftovers.

\section{Dietary diversity scores}

Dietary diversity scores were obtained using a $7 \mathrm{~d}$ recall questionnaire that was designed to capture information from the week preceding the survey. A total of thirteen food groups were assessed: the twelve food groups specified in the $\mathrm{FAO}^{(41)}$ guidelines for measuring household and individual dietary intake and an additional food group for nutritionally important forest foods ${ }^{(4)}$. The food groups were: (i) cereals and wheat products; (ii) roots and tubers; (iii) legumes and lentils; (iv) nuts; (v) dairy and fats; (vi) meat and game; (vii) poultry; (viii) fruits; (ix) fish and seafood; (x) vegetables; (xi) forest foods; (xii) alcoholic drinks; and (xiii) non-alcoholic beverages. Six varieties of foods were included in the cereals and wheat products group, five in roots and tubers, four in lentils and pulses, two in nuts, four in diary and fats, fifteen in meat and game, four in poultry, eight in fish and seafood, thirteen in vegetables, eight in fruits, four in alcoholic drinks, four in non-alcoholic beverages and seventeen in forest plant foods. A total of ninety-four food items were mentioned across these food groups (Table 2). The food items consumed were allocated among the thirteen food groups and the household dietary diversity score (HDDS) was calculated by summing the number of unique food groups consumed by each woman. The food variety score (FVS; the number of different food varieties consumed over the recall period of $7 \mathrm{~d}^{(39)}$ ) and the forest food consumption score (FFCS; the sum of the occurrences of consumption incidents of forest food items) were also calculated (see online supplementary material, Supplemental Table 2).

\section{Household food insecurity assessment}

The Household Food Insecurity Access Scale (HFIAS) was assessed following the procedure proposed by Coates et $a l^{\left({ }^{(42)}\right.}$. A set of nine standard questions was posed to women, who responded on behalf of other household members. The HFIAS score is a continuous indicator ranging from 0 (food secure) to 27 (maximum food insecurity $)^{(42)}$, with the score categorized into four levels of household food insecurity: food secure $($ score $=0$ ), mildly $\quad($ score $=1-13)$, moderately $\quad($ score $=14-16)$ or severely food insecure (score $=17-27$ ).

\section{Data analysis}

Daily nutrient intakes were computed from total food intake and from forest foods and non-forest foods separately ${ }^{(43,44)}$. Forest foods included forest plant foods, as classified under
Table 2 Proportion of households from southern and eastern Cameroon that consumed different foods in $7 d$ in May 2012

\begin{tabular}{|c|c|c|}
\hline Food group and food variety & $n$ & $\%$ \\
\hline \multicolumn{3}{|l|}{ Cereals and wheat products } \\
\hline Maize & 277 & $99 \cdot 6$ \\
\hline Rice & 276 & 99.2 \\
\hline Cake & 264 & 94.9 \\
\hline Spaghetti & 262 & 94.2 \\
\hline Bread & 251 & $90 \cdot 3$ \\
\hline Corn flour (farine de maïs) & 209 & $75 \cdot 2$ \\
\hline \multicolumn{3}{|l|}{ Roots and tubers } \\
\hline Cassava & 274 & $98 \cdot 6$ \\
\hline Taro & 273 & 98.2 \\
\hline Sweet potato & 233 & 83.8 \\
\hline Yam & 224 & 80.6 \\
\hline Wild yam (Dioscorea spp.)† & 21 & $7 \cdot 6$ \\
\hline \multicolumn{3}{|l|}{ Pulses and lentils } \\
\hline Beans & 266 & $96 \cdot 0$ \\
\hline Soyabeans & 72 & $25 \cdot 9$ \\
\hline Sesame & 26 & 9.4 \\
\hline Peas & 7 & 2.5 \\
\hline \multicolumn{3}{|l|}{ Nuts } \\
\hline Groundnuts & 277 & $100 \cdot 0$ \\
\hline Bambara groundnut (Vigna subterranea) $\dagger$ & 2 & 0.7 \\
\hline \multicolumn{3}{|l|}{ Dairy, fat and their products } \\
\hline Cooking oil & 226 & $85 \cdot 6$ \\
\hline Butter & 225 & $85 \cdot 2$ \\
\hline Milk & 217 & $82 \cdot 2$ \\
\hline Margarine & 55 & $20 \cdot 8$ \\
\hline \multicolumn{3}{|l|}{ Meat and game } \\
\hline Porcupine & 266 & $95 \cdot 7$ \\
\hline Rats & 264 & 94.9 \\
\hline Pork & 248 & 89.2 \\
\hline Snake (viper, python, etc.) & 244 & $87 \cdot 8$ \\
\hline Goat & 241 & $86 \cdot 7$ \\
\hline Beef & 238 & $85 \cdot 6$ \\
\hline Snails & 234 & $84 \cdot 2$ \\
\hline Sheep & 233 & 83.8 \\
\hline Antelope & 232 & 83.5 \\
\hline Squirrel & 201 & $72 \cdot 3$ \\
\hline Caterpillars & 184 & $66 \cdot 2$ \\
\hline Warthogs & 90 & $32 \cdot 4$ \\
\hline Eastern mole & 86 & $30 \cdot 9$ \\
\hline Guinea pig & 17 & $6 \cdot 1$ \\
\hline Rabbit & 10 & 3.6 \\
\hline \multicolumn{3}{|l|}{ Poultry } \\
\hline Chicken & 273 & $98 \cdot 9$ \\
\hline Eggs & 265 & $96 \cdot 0$ \\
\hline Wild birds & 254 & $92 \cdot 0$ \\
\hline Duck & 154 & $55 \cdot 8$ \\
\hline \multicolumn{3}{|l|}{ Fish and seafood } \\
\hline Catfish & 260 & 93.9 \\
\hline Crayfish & 257 & $92 \cdot 8$ \\
\hline Crab & 251 & $90 \cdot 6$ \\
\hline Tilapia fish & 210 & $75 \cdot 8$ \\
\hline Carp & 88 & $31 \cdot 8$ \\
\hline Nile perch & 37 & 13.4 \\
\hline Smoked fish & 32 & $11 \cdot 6$ \\
\hline Mackerel & 25 & $9 \cdot 0$ \\
\hline Sardine & 9 & 3.2 \\
\hline \multicolumn{3}{|l|}{ Vegetables } \\
\hline Onions & 277 & 99.6 \\
\hline Tomatoes & 276 & $99 \cdot 3$ \\
\hline Cassava leaves & 274 & $98 \cdot 6$ \\
\hline Red pepper & 273 & $98 \cdot 2$ \\
\hline Cucumber & 271 & 97.5 \\
\hline Taro leaves & 225 & $80 \cdot 9$ \\
\hline African eggplant (Solanum nigrum) $\dagger$ & 198 & $71 \cdot 2$ \\
\hline Spinach & 117 & $42 \cdot 1$ \\
\hline Cauliflower & 52 & $18 \cdot 7$ \\
\hline Sweet potato leaves & 52 & $18 \cdot 7$ \\
\hline Cowpea leaves & 3 & $1 \cdot 1$ \\
\hline
\end{tabular}


Table 2 Continued

\begin{tabular}{|c|c|c|}
\hline Food group and food variety & $n$ & $\%$ \\
\hline Pumpkin leaves & 3 & $1 \cdot 1$ \\
\hline Amaranth (leaves) & 1 & 0.4 \\
\hline \multicolumn{3}{|l|}{ Fruits } \\
\hline Avocado & 278 & $100 \cdot 0$ \\
\hline Plantains & 278 & $100 \cdot 0$ \\
\hline Mangoes & 275 & 98.9 \\
\hline Papaya & 275 & 98.9 \\
\hline Orange & 272 & $97 \cdot 8$ \\
\hline Pineapple & 269 & $96 \cdot 8$ \\
\hline Guavas & 265 & $95 \cdot 3$ \\
\hline Passion fruits & 15 & $5 \cdot 4$ \\
\hline \multicolumn{3}{|l|}{ Forest plant foods } \\
\hline Bush mangoes (Irvingia gabonensis) & 262 & $94 \cdot 2$ \\
\hline Wild citron (Citrus spp.)† & 236 & 84.9 \\
\hline Moabi (Baillonella toxisperma) & 212 & $76 \cdot 3$ \\
\hline Ngoyo/boutoh/mvout (Trichoscypha abut) & 207 & 74.4 \\
\hline Ntom (Pachypodanthium staudtii) & 67 & $24 \cdot 1$ \\
\hline Noisettes (Coula edulis) & 59 & $21 \cdot 2$ \\
\hline Ngong (Klainedoxa gabonensis) & 58 & $20 \cdot 9$ \\
\hline Djansang (Ricinodendon heudoliti) & 49 & $17 \cdot 6$ \\
\hline Mbivoe (Cola pachycarpa) & 27 & 9.7 \\
\hline Cola (Cola spp.) & 19 & $6 \cdot 8$ \\
\hline Mushroom (Termitomyces spp.) & 16 & $5 \cdot 8$ \\
\hline Corrosolsauvage (Annonidium mannii) & 15 & 5.4 \\
\hline Bitter cola (Garcina kola) & 14 & $5 \cdot 0$ \\
\hline Rondelle (Afrostyrax lepidophyllus) & 13 & 4.7 \\
\hline Kana (Pogo oleosa)† & 13 & 4.7 \\
\hline Ebaye (Pentaclethra macrophylla Benth) & 5 & 1.8 \\
\hline Ofos & 3 & $1 \cdot 1$ \\
\hline \multicolumn{3}{|l|}{ Alcoholic beverages } \\
\hline Beer & 235 & $97 \cdot 1$ \\
\hline Wine & 195 & $80 \cdot 1$ \\
\hline Traditional beer & 172 & $71 \cdot 1$ \\
\hline Spirit & 161 & 66.5 \\
\hline \multicolumn{3}{|l|}{ Non-alcoholic beverages } \\
\hline Coffee & 191 & $89 \cdot 3$ \\
\hline Chocolate & 150 & $70 \cdot 1$ \\
\hline Tea & 123 & 57.5 \\
\hline Soya milk & 26 & $12 \cdot 1$ \\
\hline
\end{tabular}

Data presented are number of households and percentage of the total number of households.

†Wild forest food varieties domesticated.

the $7 \mathrm{~d}$ recall questionnaire, wild animal meat and semi-wild vegetables, fruits, nuts, roots and tubers. Mean nutrient intakes were calculated from the quantity consumed daily, derived from an average of the two $24 \mathrm{~h}$ recalls, using the computer program Nutrisurvey ${ }^{\circledR}$ 2013, which provides nutrient values associated with specific quantities of foods. Nutrient compositions for foods which were not found in the Nutrisurvey program were derived from the West African food composition table ${ }^{(45)}$, the Cameroonian foods nutrient composition data ${ }^{(15,37,38,46)}$, Democratic Republic of Congo (DR Congo) data ${ }^{(12)}$ and the US Department of Agriculture nutrient database (http://ndb.nal.usda.gov/ndb/search/list). Average micronutrient intakes were compared with the estimated average requirements (EAR) ${ }^{(44)}$ and the proportions of women with inadequate intake were computed. The EAR is the average daily nutrient intake estimated to meet the needs of half the healthy individuals in a particular age and gender group $^{(43)}$. The bioavailability of each nutrient was taken into consideration when calculating nutrient intakes ${ }^{(43,44)}$.
The energy and nutrient intakes and the number of food groups consumed in the two non-consecutive $24 \mathrm{~h}$ recalls were determined. ANOVA with Tukey post hoc testing was then used to compare results between women who consumed forest foods in this period and those who did not. The average percentages of women with micronutrient intakes below the EAR were computed ${ }^{(43)}$. Owing to Fe requirements among premenopausal women not having a normal distribution, the probability approach was used to estimate the prevalence of inadequate Fe intakes ${ }^{(47)}$.

To assess how forest foods contribute to food security, logistic regression analysis and Spearman's correlation analyses were performed. Logistic regression was performed to assess the risk of food insecurity among forest food consumers in comparison to non-forest food consumers. Respondents were dichotomized into food secure and food insecure, the latter including those who were suffering from mild, moderate and severe food insecurity. Crude odds ratios with $95 \%$ confidence intervals were used for interpretation and reporting of results. Spearman rank correlation analyses were conducted to assess the association of forest foods with food security and the strength of the relationship among HFIAS, FFCS, HDDS and FVS. All data were analysed using the statistical software package IBM SPSS Statistics Version 21.0 and statistical significance was set at $\alpha=0.05$ for all tests.

\section{Results}

\section{Respondent characteristics}

The household heads averaged 44 years of age, with the majority having attended or completed primary school (64\%) and more than half (56\%) having a large number of household dependants (five to nine; Table 1). Approximately three-quarters (75\%) of the respondents were natives of the study area and $62 \%$ fetched water from ponds. About $97 \%$ used firewood for cooking and $67 \%$ used kitchen firewood as their source of lighting. Despite being forest-dependent communities, the majority of the respondents were farmers (52\%) with a high knowledge of forest foods. Based on the HFIAS score, more than threequarters of all households ( $83 \%$ ) were food insecure; nearly half $(47 \%)$ of households suffered from mild food insecurity, while $29 \%$ suffered from severe food insecurity.

\section{Knowledge of forest food species}

Forty-seven forest food species belonging to thirty-six families were named by respondents as important forest food species (see online supplementary material, Supplemental Table 1 ). The majority ( $n$ 44) of species were cooked while only three were eaten raw. Most of the species ( $n$ 33) were eaten as leafy vegetables, twenty-three as fruits, three as tubers, three as nuts, and two were kept as seed or consumed. Plant species from which leafy greens were 
consumed included Aframomun spp., G. africanum, Canarium occidentale, Amaranthus bybridus, Coula edulis and Afrostyrax lepidophyllus. Species whose fruits were consumed as snacks included Aframomun spp., Baillonella toxisperma, I. gabonensis, Carica papaya and Citrus spp. The tubers listed as major sources of energy included Dioscorea spp. and Xanthosomas agittifolium. Some sources of greens such as A. bybridus and Solanum nigrum, fruits such as Citrus spp. and Musa spp., and starchy staples such as Dioscorea spp. are cultivated but were listed by respondents as wild because they are harvested from the forest. In the present paper they are referred to as 'semi-wild'. Another important category of forest foods comprised native forest tree species of which fruits and/or seeds are consumed, notably Pentaclethra macrophylla, I. gabonensis and B. toxisperma. The seeds/fruits of B. toxisperma are also used by the local communities to produce an edible oil that is used for cooking and the surplus is sold to buy basic household items.

Of the 279 women surveyed, 272 (98\%) reported consuming at least one forest food during the last week (Table 2 and online supplementary material, Supplemental Table 2). Among the plant species, I. gabonensis was the most frequently consumed forest plant species and was named in $94 \%$ of the recalls. I. gabonensis (bush mango) is popular and liked by children because of its sweet and nutritious yellow pulp ${ }^{(48)}$. The nut of I. gabonensis is dried and pounded to produce edible cooking oil that is used in cooking, while surplus oil is sold. Among the forest animal species, porcupines were the most frequently consumed and were named in $96 \%$ of the $7 \mathrm{~d}$ recall data.

\section{Consumption frequency of cultivated and forest foods}

Fruits were the only group eaten by all respondents, with most consuming seven different fruits in the last week (Table 2). Nuts and cereals were consumed by most respondents (99\%), who reported eating six species of cereal and two species of nut. The food groups with the largest number of different food items were the forest food group with seventeen unique items, vegetables with thirteen unique items, and meat with fourteen unique items. The meat food group was predominantly comprised of various species of wild-captured animals.

Among the starchy staples, cereals and wheat products and roots and tubers were consumed the most frequently. The most frequently consumed staple food items were plantains, maize, rice and cassava. Avocado, tomatoes, onions and cassava leaves constituted the main side dishes for the majority of households. Groundnuts formed an important ingredient of sauces. Under the meat and game category, porcupines and edible rats were the most consumed, while within the poultry, fish and seafood group, chicken and catfish were the most consumed. Under the forest foods category, seventeen foods were found to contribute substantially to the diets of the study populations (Table 2). Most consumed were I. gabonensis (bush mango), a native wild fruit, and non-native oranges, Citrus spp. (semi-wild oranges). Semi-wild yams (Dioscorea spp.) and Bambara groundnuts (Vigna subterranea) made substantial contributions to the food groups roots and tubers and nuts, respectively. Greens of $S$. nigrum and $A$. bybridus were among the widely consumed vegetables.

\section{Food variety score, dietary diversity score and forest food consumption score}

Respondents' FVS for the $7 \mathrm{~d}$ preceding the interview ranged from 11 to 23 (see online supplementary material, Supplemental Table 2). Each individual consumed between eleven and twenty-three foods during the $7 \mathrm{~d}$ recall period. The majority of respondents $(67 \%)$ consumed fifteen to nineteen different food items over the $7 \mathrm{~d}$ period.

Sixty per cent of the respondents ate items from all thirteen food groups during the $7 \mathrm{~d}$ recall period (see online supplementary material, Supplemental Table 2), while 94\% had DDS of 12-13 (consumed food items from twelve or thirteen food groups). The FFCS ranged from 1 to 8 , with the largest group (32\%) reporting having eaten three forest food items during the $7 \mathrm{~d}$ recall period. Four respondents (1\%) reported eating eight different forest food items (Supplemental Table 2). Based on these patterns, 272 respondents (98\%) were considered forest food consumers and $2 \%$ did not consume any forest-derived foods.

\section{Relationship between forest food consumption and food insecurity}

Logistic regression analysis revealed that forest food consumers were 7.5 times (OR $=7.5 ; 95 \%$ CI $0 \cdot 31,10 \cdot 9$; $P=0.0001$ ) more likely to be food insecure compared with non-forest food consumers. Forest food consumers suffered most from mild food insecurity (Table 3). Within the forest food consumers, the mean HFIAS score was found to be significantly and inversely correlated with the FFCS

Table 3 Food insecurity among forest food consumers and nonforest food consumers in southern and eastern Cameroon in May 2012

\begin{tabular}{lccc}
\hline & $\begin{array}{c}\text { Percentage } \\
\text { among forest food } \\
\text { consumers } \\
(n \text { 239) }\end{array}$ & $\begin{array}{c}\text { Percentage } \\
\text { among non-forest } \\
\text { food consumers } \\
\text { (n 40)§ }\end{array}$ & $\begin{array}{c}P \\
\text { value }\end{array}$ \\
\hline HFIAS† & 18.8 & 2.6 & $<0.0001$ \\
Mild (1-13) & 67.5 & 71.8 & $<0.0001$ \\
Moderate (14-16) & 7.9 & 5.1 & $<0.0001$ \\
Severe (17-27) & 5.8 & 20.5 & $<0.0001$ \\
\hline
\end{tabular}

†Household Food Insecurity Access Scale; total score (range 0-27) is calculated from the individual scores of the nine frequency-of-occurrence questions and categorized into four levels of household food insecurity. Numbers in parentheses represent the cut-off of HFIAS score for each food security category.

¥Eating at least one forest food in the $7 \mathrm{~d}$ recall period.

$\S$ Did not eat forest foods in $7 \mathrm{~d}$ recall period. 
$\left(r^{2}=-0 \cdot 169, P=0 \cdot 0006\right)$. This suggests that households that consumed more forest foods were less food insecure (Table 4). Statistically significant positive correlations between the FFCS and the FVS $\left(r^{2}=0.091\right)$ and between the FFCS and the HDDS $\left(r^{2}=0.006\right)$ further supported the association between higher forest food consumption and reduced risk of food insecurity.

\section{Micro- and macronutrient intakes of respondents}

Approximately $70 \%$ of the respondents had $\mathrm{Fe}, \mathrm{Na}, \mathrm{Mg}, \mathrm{Zn}$, vitamin $\mathrm{C}$ and vitamin $\mathrm{A}$ intakes above the EAR (see online supplementary material, Supplemental Table 3). The daily energy intake from forest foods compared with non-forest foods was low (Table 5). Despite the low energy intake from forest foods, these foods made a substantial contribution

Table 4 Spearman's correlation matrix of food security indicators for forest communities of southern and eastern Cameroon in May 2012

\begin{tabular}{lclll}
\hline $\begin{array}{l}\text { Household food } \\
\text { security indicator }\end{array}$ & HDDS & FFCS & FVS & $\begin{array}{c}\text { HFIAS } \\
\text { score }\end{array}$ \\
\hline HDDS† & 1 & $0.006^{\star}$ & $0.560^{\star \star}$ & $-0.029^{\star}$ \\
FFCS $\ddagger$ & & 1 & $0.091^{\star}$ & $-0.169^{\star *}$ \\
FVS & & & 1 & -0.005 \\
HFIAS score & & & & 1 \\
\hline
\end{tabular}

HDDS, household dietary diversity score; FFCS, forest food consumption score; FVS, food variety score; HFIAS, Household Food Insecurity Access Scale.

${ }^{*}$ Correlation is significant at the $5 \%$ level.

${ }^{* *}$ Correlation is significant at the $1 \%$ level.

†The maximum score includes thirteen food groups.

$\ddagger$ Only forest food species were included in the count group.
(>60\%) to the intakes of vitamins A, E and C, Fe, Zn K, Ca, $\mathrm{Mg}$ and $\mathrm{Na}$ in the two $24 \mathrm{~h}$ recalls (Table 5).

\section{Contribution of forest foods to macro- and micronutrient intakes}

Among the forest food groups consumed, vegetables, mainly S. nigrum, and fats and oils, principally Elaeis guineensis (palm oil), contributed remarkably high intakes of vitamin A compared with other food groups (76 and $21 \%$, respectively; Table 6). Bush meat (porcupine and rats), roots and tubers (Dioscorea spp.) and vegetables (Annonidium mannii and S. nigrum) contributed significantly to $\mathrm{Fe}$ and $\mathrm{Zn}$ intakes (Table 6). Among the forest foods mentioned in the two $24 \mathrm{~h}$ recalls, within the wild forest plant food group, notable contributions to micronutrient intakes were provided by the species Dacryodes edulis, I. gabonensis and P. macrophylla. These wild plant species accounted for $4.6 \%$ of Fe intakes, $2.5 \%$ of vitamin $\mathrm{A}$ intakes and $1 \%$ of both energy and $\mathrm{Zn}$ intakes compared with the nutrients and energy provided solely by forest foods.

\section{Discussion}

\section{Contribution of forest foods to nutrient and energy intakes}

In our survey of women in rural Cameroon, we found that those reporting forest foods in the $24 \mathrm{~h}$ recalls obtained a substantial proportion of their intake of vitamins $\mathrm{A}, \mathrm{C}$ and $\mathrm{E}$, $\mathrm{Ca}, \mathrm{Fe}, \mathrm{Zn}, \mathrm{Mg}, \mathrm{K}$ and $\mathrm{Na}$ from forest foods when compared

Table 5 Daily dietary nutrient intakes from forest-derived and non-forest foods by non-pregnant, non-lactating women in southern and eastern Cameroon during two $24 \mathrm{~h}$ recalls conducted in May 2012

\begin{tabular}{|c|c|c|c|c|c|c|c|}
\hline \multirow[b]{3}{*}{ Nutrient } & \multicolumn{7}{|c|}{ Forest foods consumed in two non-consecutive $24 \mathrm{~h}$ recalls } \\
\hline & \multicolumn{3}{|c|}{ Yes $(n$ 46) } & \multicolumn{3}{|c|}{ No (n 233) } & \multirow[b]{2}{*}{$P$ value } \\
\hline & Mean & SD & $\%$ of women below EAR† & Mean & SD & $\%$ of women below EAR† & \\
\hline Weight $(\mathrm{g})$ & $1116 \cdot 9^{\mathrm{a}}$ & 34.4 & - & $1311 \cdot 3^{\mathrm{b}}$ & $131 \cdot 3$ & - & $<0.0001$ \\
\hline Energy $(\mathrm{kJ}) \S$ & $11339 \cdot 1^{\mathrm{a}}$ & $20656 \cdot 8$ & 51.9 & $7805 \cdot 3^{b}$ & 3477.7 & $36 \cdot 2$ & $<0.0001$ \\
\hline Energy (kcal)§ & $2710 \cdot 1$ & $4937 \cdot 1$ & $51 \cdot 9$ & $1865 \cdot 5$ & $831 \cdot 2$ & $36 \cdot 2$ & $<0.0001$ \\
\hline Protein (g) & $79 \cdot 1^{a}$ & $198 \cdot 5$ & $47 \cdot 4$ & $31.9^{b}$ & $127 \cdot 5$ & $41 \cdot 3$ & $<0.0001$ \\
\hline Fat $(\mathrm{g})$ & $77 \cdot 7^{\mathrm{a}}$ & $249 \cdot 8$ & 35.5 & $20 \cdot 9^{b}$ & $20 \cdot 9$ & $40 \cdot 7$ & $<0.0001$ \\
\hline Carbohydrate (g) & $141 \cdot 2^{a}$ & $350 \cdot 2$ & $67 \cdot 0$ & $320 \cdot 7^{b}$ & $909 \cdot 2$ & $41 \cdot 3$ & $<0.0001$ \\
\hline Dietary fibre (g) & $35 \cdot 5^{\mathrm{a}}$ & 234.9 & $72 \cdot 0$ & $36 \cdot 2^{b}$ & $126 \cdot 8$ & $49 \cdot 1$ & 0.192 \\
\hline Vitamin $A(\mu g)$ & $6155 \cdot 3^{a}$ & $4907 \cdot 3$ & $7 \cdot 1$ & $1801 \cdot 7^{\mathrm{b}}$ & $944 \cdot 3$ & $10 \cdot 8$ & 0.033 \\
\hline Vitamin $E$ equivalents (mg) & $8 \cdot 4^{\mathrm{a}}$ & $46 \cdot 9$ & $38 \cdot 2$ & $4 \cdot 4^{\mathrm{b}}$ & $15 \cdot 3$ & $48 \cdot 3$ & 0.041 \\
\hline Vitamin C (mg) & $81 \cdot 8^{\mathrm{a}}$ & $255 \cdot 7$ & $21 \cdot 3$ & $228 \cdot 8^{b}$ & $710 \cdot 3$ & $16 \cdot 5$ & 0.013 \\
\hline $\mathrm{Na}(\mathrm{mg})$ & $448 \cdot 5^{a}$ & $161 \cdot 6$ & 0.0 & $130 \cdot 1^{\mathrm{b}}$ & $167 \cdot 5$ & 0.0 & $<0.0001$ \\
\hline $\mathrm{K}(\mathrm{mg})$ & $5481 \cdot 8^{a}$ & $3228 \cdot 6$ & $28 \cdot 0$ & $1405 \cdot 9^{b}$ & $234 \cdot 1$ & $13 \cdot 2$ & $<0.0001$ \\
\hline $\mathrm{Ca}(\mathrm{mg})$ & $1466 \cdot 4^{\mathrm{a}}$ & $9313 \cdot 8$ & $11 \cdot 2$ & $541.9^{b}$ & $508 \cdot 2$ & $19 \cdot 3$ & $<0.0001$ \\
\hline $\mathrm{Mg}(\mathrm{mg})$ & $2110 \cdot 5^{a}$ & 1631.9 & 11.4 & $965 \cdot 8^{b}$ & $740 \cdot 8$ & $1 \cdot 1$ & $<0.0001$ \\
\hline$P(\mathrm{mg})$ & $5681 \cdot 5^{\mathrm{a}}$ & 5234.6 & 44.9 & $1821 \cdot 1^{b}$ & $2352 \cdot 0$ & $41 \cdot 8$ & $<0.0001$ \\
\hline $\mathrm{Fe}(\mathrm{mg})$ & $27 \cdot 8^{a}$ & $116 \cdot 7$ & $15 \cdot 4$ & $13 \cdot 1^{\mathrm{b}}$ & $32 \cdot 1$ & $10 \cdot 2$ & $<0.0001$ \\
\hline $\mathrm{Zn}$ (mg) & $55 \cdot 3^{a}$ & $418 \cdot 6$ & $12 \cdot 0$ & $42 \cdot 3^{b}$ & 265.9 & 2.9 & $<0.0001$ \\
\hline
\end{tabular}

†Percentage of women below the estimated average nutrient requirement (EAR) for adults ${ }^{(39,40)}$.

$\ddagger$ At $P=0.05$, a Tukey post hoc test was performed, using ANOVA for comparison of means of the two food categories. Mean values within a row with unlike superscript letters were significantly different at the 0.05 level.

$\S$ Total energy includes energy from alcoholic and non-alcoholic beverages. 
Table 6 Vitamin A, iron, zinc and energy intakes, according to food groups derived from forest foods and non-forest foods, by non-pregnant, non-lactating women in the two $24 \mathrm{~h}$ recalls in southern and eastern Cameroon conducted in May 2012

\begin{tabular}{|c|c|c|c|c|c|c|c|c|}
\hline \multirow[b]{3}{*}{ Food group } & \multicolumn{8}{|c|}{ Contribution based on two non-consecutive $24 \mathrm{~h}$ recalls } \\
\hline & \multicolumn{4}{|c|}{ Forest foods ( $n$ 46) } & \multicolumn{4}{|c|}{ Non forest foods ( $n$ 233) } \\
\hline & $\begin{array}{c}\% \text { of total } \\
\text { vitamin } A \text { in } \\
\text { forest foods } †\end{array}$ & $\begin{array}{l}\% \text { of total } \\
\text { Fe in forest } \\
\text { foods }\end{array}$ & $\begin{array}{l}\% \text { of total } \\
\mathrm{Zn} \text { in forest } \\
\text { foods } †\end{array}$ & $\begin{array}{c}\% \text { of total } \\
\text { energy in } \\
\text { forest foods } †\end{array}$ & $\begin{array}{l}\% \text { of total } \\
\text { vitamin } \mathrm{A} \text { in non- } \\
\text { forest foods } †\end{array}$ & $\begin{array}{c}\% \text { of total } \mathrm{Fe} \\
\text { in non-forest } \\
\text { foods } †\end{array}$ & $\begin{array}{c}\% \text { of total } \mathrm{Zn} \\
\text { in non-forest } \\
\text { foods } †\end{array}$ & $\begin{array}{l}\% \text { of total } \\
\text { energy in non- } \\
\text { forest foodst }\end{array}$ \\
\hline Meat & 0.7 & 28.0 & $40 \cdot 0$ & $3 \cdot 8$ & 0 & 0 & 0 & 0 \\
\hline Fish & 0 & 0 & 0 & 0 & 1.9 & 23.9 & $16 \cdot 2$ & 22.9 \\
\hline Non-alcoholic beverages & 0 & 0 & 0 & 0 & 0 & 3.1 & 0 & 0.1 \\
\hline Fruits & 0 & 0 & 0 & 0 & 4.2 & 8.0 & 1.4 & $47 \cdot 1$ \\
\hline Roots and tubers & 0 & $30 \cdot 6$ & 34.7 & 93.2 & $5 \cdot 8$ & $29 \cdot 4$ & 24.9 & $13 \cdot 8$ \\
\hline Cereals and wheat products & 0 & 0 & 0 & 0 & $5 \cdot 3$ & $21 \cdot 2$ & $10 \cdot 6$ & $10 \cdot 4$ \\
\hline Pulses and lentils & 0 & 0 & 0 & 0 & $1 \cdot 1$ & 1.9 & 0.5 & 0.2 \\
\hline Nuts & 0 & 0 & 0 & 0 & 0.1 & 3.2 & 2.5 & 3.7 \\
\hline Oil, fats, milk and dairy products & $20 \cdot 7$ & 0.1 & 0.01 & 0.9 & 0.4 & 0.1 & 0.3 & 1.0 \\
\hline Vegetables & $76 \cdot 1$ & $36 \cdot 5$ & $24 \cdot 2$ & $1 \cdot 1$ & $80 \cdot 2$ & $8 \cdot 6$ & 43.6 & 0.3 \\
\hline Poultry & 0 & 0 & 0 & 0 & 1.0 & 0.7 & 0.3 & 0.3 \\
\hline Wild forest plant food species $\ddagger$ & 2.5 & $46 \cdot 0$ & $1 \cdot 1$ & 1.0 & 0 & 0 & 0 & 0 \\
\hline
\end{tabular}

†Expressed as percentage of total vitamin A, Fe, $\mathrm{Zn}$ and energy content among the forest foods or non-forest foods only.

$¥$ Wild forest plant food group species are collected only from forests, while the other food groups under the forest foods category are either collected from forests or have been domesticated.

with those who did not mention forest foods in the $24 \mathrm{~h}$ recalls. This finding is important because low intakes of vitamin $\mathrm{A}, \mathrm{Fe}$ and $\mathrm{Zn}$ are established risk factors for poor nutritional status in most African populations, including forest-dependent communities ${ }^{(49)}$. Although having lower micronutrient intakes overall, those who ate forest foods obtained much of their vitamin A intake from forest food vegetables, and much of their Fe and $\mathrm{Zn}$ intakes from bush meat and forest food root and tuber groups. In addition, the consumption of forest foods was significantly related to increased dietary diversity. Previous findings ${ }^{(50,51)}$ have correlated the increased consumption of wild foods to increased age of the household head, low education levels and a large number of household dependants, characteristics also observed in the present study. The findings in the present study indicated that forest foods, such as bush meat including edible rats, porcupines and snails, and wild vegetables, notably A. mannii, S. nigrum and Vernonia amygdalina, were widely consumed. These foods could explain the high protein, fat and micronutrient intakes from forest foods among forest food consumers. Among the forest food consumers, the wild yams of Dioscorea spp. alone contributed $93 \%$ of the total energy derived from forest foods. Forest foods were also observed to play a complementary role to non-forest foods, rather than being a substitute. Those who did not consume forest foods in the two $24 \mathrm{~h}$ recalls in the present study did not consume meat and meat products, while bush meat was predominantly consumed by those who consumed forest foods. This is in contrast with the findings reported among rural populations of South Africa which indicated that wild vegetables are consumed only when meat and exotic vegetables cannot be afforded ${ }^{(52)}$. Nevertheless, the nutrient intakes from forest foods in the present study are higher than those reported in similar studies conducted in DR Congo ${ }^{(12)}$ and Benin ${ }^{(53)}$. Research conducted with the Kisangani and Turumbu forest communities of DR Congo indicated that forest foods do not provide adequate intakes of the micronutrients $\mathrm{Fe}, \mathrm{Zn}, \mathrm{Ca}$ and vitamin $\mathrm{B}_{12}$, with less than $25 \%$ of women having intakes above the $\mathrm{RDA}^{(12)}$. The low contribution of forest foods towards meeting the EAR of these micronutrients has also been reported among the Lama Forest communities of Benin $^{(53)}$. The lower nutrient contributions of forest foods in Benin $^{(53)}$ and DR Congo ${ }^{(12)}$ than in the present study may be attributable to the exclusion of nutrient-rich animal foods.

The findings in the present study revealed that hunting and collecting wild forest foods was an important household activity among Cameroonian populations, providing protein and essential micronutrients to vulnerable household members. Dietary intake analysis revealed that bush meat provided substantial amounts of the total intakes of Fe and $\mathrm{Zn}$, while wild vegetables provided the majority of vitamin A content obtained from the forest foods consumed. Furthermore, the $24 \mathrm{~h}$ recall results indicated that bush meat was the only form of meat consumed the previous day among all 279 households interviewed, while the $7 \mathrm{~d}$ recall data revealed that the most widely consumed meat was that of porcupines and edible rats. Similarly, communities of Yassa, Mvae and Bakola in Cameroon were reported to obtain $70-80 \%$ of their protein and considerable amounts of micronutrients, including vitamin A, riboflavin and niacin, from hunting ${ }^{(54,55)}$. Keegan ${ }^{(56)}$ also reported that hunting is a major source of protein for rural communities.

Data from the two $24 \mathrm{~h}$ recall periods showed a remarkably high contribution to energy from the roots and tubers food group among forest food consumers. The semi-wild yam Dioscorea spp. was the only root and tuber that contributed $93 \%$ of the total energy from forest foods. The non-forest food consumers did not consume any form of animal food, limiting their access to essential nutrients. The key background informers for the present study 
reported that Dioscorea spp. acts as a source of dietary energy for most forest families, especially the Baka pygmies who do not have gardens to plant cultivated staples. The energy contribution from wild plant forest food species in the present study is quite similar to that reported in the Usambara forests in Tanzania ${ }^{(57)}$, the Mekong delta of Vietnam $^{(58)}$ and the Kisangani forests in DR Congo ${ }^{(12)}$. Wild forest foods contributed $2 \%$ to total energy in Tanzania and $1.1 \%$ in DR Congo. The low contribution of forest plant food species to energy and other nutrient intakes can be attributed to the fact that forest plant foods are consumed in very small quantities, as fruit snacks between meals or as vegetables or sauces.

\section{Contribution of forest foods to food security}

Despite logistic regression modelling revealing that respondents who consumed forest foods were more likely to be food insecure, correlation analysis revealed that greater forest food consumption was significantly and positively related to increased dietary diversity among the forest food consumers. The significant inverse correlation between FFCS and HFIAS, and the positive correlation between FFCS and HDDS and FVS, indicate that forest foods may play an important role in household food security.

The measures FFCS, HDDS and FVS are useful indicators of household food security ${ }^{(8,59,60)}$ and good proxies of overall dietary quality ${ }^{(61,62)}$. In north-west Benin, a higher diversity score was reported among the populations residing near or inside the government-owned wild fruit tree reserves than among the populations in urban centres, and this was attributed to increased consumption of forest tree foods ${ }^{(60)}$. The high prevalence of food insecurity among the study respondents may be due to the high proportion of respondents $(\sim 50 \%)$ relying on illegal logging, hunting and poaching for income, the majority having low levels of education and having a large number of household dependants. Also, the observed low volumes of forest foods consumed in the present study and seasonality ${ }^{(10)}$ may be additional factors contributing to the high incidence of food insecurity among forest food consumers. Levang et al. ${ }^{(63)}$ also reported that the forest food hunters and gatherers in southern and eastern Cameroon suffer worse food insecurity than those practising agriculture. Similar studies conducted among the forest communities of DR Congo ${ }^{(12)}$ and Benin ${ }^{(53)}$ revealed that despite the communities having access to an environment rich in forest foods, low dietary intake and high food insecurity were rampant. The seasonality of forest foods, the annual and regional variations in food availability, and the small portion sizes of forest foods consumed were reported to be major contributors to food insecurity in DR Congo $^{(12)}$, Benin ${ }^{(53)}$ and Burkina Faso ${ }^{(64)}$. Other scholars have observed that dietary fat and other energy sources are limited in Congo Basin forest communities, leading to food insecurity ${ }^{(65)}$. Further studies are needed to clarify these relationships, including investigating the factors affecting food security and how forest foods can be promoted to combat the high food insecurity levels.

Our finding of an inverse correlation between food insecurity and dietary diversity is in agreement with other studies, including among children and women of Awajún forest communities of Peru ${ }^{(10)}$, pre-school children in northern Ghana ${ }^{(66)}$, rural household farmers of northern Ethiopia $^{(67)}$ and cotton-growing women farmers in Burkina Faso ${ }^{(64)}$. Among the Awajún community of the Amazonian forests of Peru, Roche et al. ${ }^{(10)}$ observed a positive relationship between the traditional forest food diversity score and nutrient dietary quality and food security. The dietary intakes, food groups and food supply were substantially high among the forest-dependent women and children living in the lower Cenepa River region of the Awajún community ${ }^{(10)}$. Most previous food diversity studies in which household food insecurity was also assessed have focused on overall dietary diversity measured by either conventional food groups or individual food items over a fixed period of time ${ }^{(68)}$. However, in the present study we included forest foods (FFCS) to the list of commonly used dietary diversity indicators that assessed household food security. Inclusion of the FFCS indicator was an appropriate measure for the forest communities in southern and eastern Cameroon because of the biodiversity of forest foods used in local diets and the high nutrient content of several of these foods ${ }^{(15,39,63)}$.

\section{Knowledge of forest foods}

The findings in the present study corroborate the previous findings in DR Congo ${ }^{(12)}$, Benin ${ }^{(53)}$, Tanzania ${ }^{(57)}$, Ethiopia ${ }^{(69)}$ and Cameroon ${ }^{(70)}$ that indicated a wide gap between the number of traditionally known and the number of commonly consumed forest foods. The focus group respondents in the present study revealed a list of forty-seven forest plant foods, of which only seventeen were observed to be consumed during the $7 \mathrm{~d}$ recall period in the study. We expected forest foods to be consumed more frequently and in larger quantities, given that $100 \%$ of the interviewed respondents reported that they often consumed forest foods. However, the study was limited by the seasonal availability of forest plant foods. Among the Lama Forest community of Benin ${ }^{(53)}$, eight of the sixty-one known wild species were found to be prepared in the local diets. Among the local residents of Hamar and Konso regions of Ethiopia, fifteen wild edible species were identified and reported to be important ${ }^{(69)}$, while in DR Congo ${ }^{(12)}$, only fifteen forest food species were consumed daily. Among the Usambara forest communities of Tanzania, ninety-two wild edible species were described, of which twenty-six were consumed and exclusively obtained from forests ${ }^{(57)}$. Among the Guiziga tribe in the far north of Cameroon, twenty-four forest and wild foods were identified as being important, but few of these foods were eaten daily ${ }^{(66)}$. Previous studies indicate that forest food consumers 
in southern and eastern Cameroon appreciated forest foods for being tasty, healthy, nutritious, part of their forest community culture and also that many forest foods had market and commercial potential ${ }^{(15,63)}$. However, advocating for an increase in knowledge and consumption of forest foods alone will not suffice to tackle the nutritional problems encountered by the local populations in southern and eastern Cameroon. The potential of forest foods to contribute to food and nutrition security has been neglected for decades and needs crucial reorganization ${ }^{(24)}$. National and regional policy makers, researchers, development agencies, community-based organizations and local populations need to invest in agroforestry and agrobiodiversity. Integration of traditional fruit trees, vegetables, wild edible animals, tubers such as wild yam and others into agroforestry systems and home gardens for better food and nutrition security, sustainability and biodiversity conservation should be promoted.

\section{Conclusions}

As a result of the high incidence of food insecurity (83.5\%) among our sample populations, food and nutrition insecurity was not alleviated by access to a large number of nutritious forest foods from a highly biodiverse forest environment. However, those who consumed forest foods obtained substantial amounts of the essential nutrients vitamin A, Fe, $\mathrm{Zn}$ and $\mathrm{Na}$ from forest foods. Forest foods, if consumed in adequate quantities, have the potential to improve dietary diversity, food security and nutrient adequacy for forest communities in Cameroon.

Given that more than $52 \%$ of the study population depends on farming as the major household economic activity, investing resources in agricultural interventions and policies alongside promotion of the use of nutrientrich forest foods to complement the diet would improve health, nutrition and food security, and is therefore paramount. Urgent action is required for the promotion, domestication and conservation of these nutrient-rich forest foods and for the preservation of traditional knowledge before these are lost. The health and nutrition sectors in Cameroon can adopt strategies and policies facilitating the transformation of forest and land use, emphasizing the domestication and commercialization of forest foods, to stimulate accessibility and availability of forest foods for the local populations. This would complement existing national and international interventions aimed at eradicating malnutrition among forest-dependent communities. There is need to explore the different roles forest foods can play in the diets of local communities across disciplines and governance institutions including forestry, agriculture, human health and nutrition, and the food industry. In addition, the programmes promoting increased consumption of forest foods for nutrition and food security can integrate strategies such as income generation through forest commercialization and/or participatory domestication of priority forest foods.

\section{Acknowledgements}

Acknowledgements: The authors wish to thank the field assistants and the village key informants for assistance with data collection in forest concessionaires of the southern site (FIPCAM) and eastern site (SCTB). Financial support: The authors wish to thank the Congo Basin Forest Fund (CBFF) of the African Development Bank and the CGIAR Research Programme on Forests, Trees and Agroforestry for funding support. The funders had no role in the design, analysis or writing of this article. Conflict of interest: None declared. Authorship: R.F. led the data collection process, performed statistical analysis and drafted the manuscript. J.M., M.K., A.K., C.A.O., P.D., O.T., J.C.T., J.L. and L.S. contributed to conception and design of the protocol, supervised the study and revised critically the manuscript. All authors read and approved the final manuscript. Ethics of buman subject participation: This study was conducted according to guidelines laid down in the Declaration of Helsinki and all procedures involving human subjects were approved by the ethical committees of the forestry and health departments of Bertoua City, the capital of the east region, and Ebolowa City, the capital of the south region. The thirty-six chiefs of the selected villages approved the research protocol. Informed oral consent was also obtained from the participating household heads.

\section{Supplementary material}

To view supplementary material for this article, please visit http://dx.doi.org/10.1017/S1368980016001324

\section{References}

1. Food and Agriculture Organization of the United Nations, International Fund for Agricultural Development \& World Food Programme (2014) The State of Food Insecurity in the World 2014. Strengthening the Enabling Environment for Food Security and Nutrition. Rome: FAO; available at http://www.fao.org/publications/sofi/2014/en/

2. Chennai Platform for Action (2005) Agricultural biodiversity and elimination of hunger and poverty: UN Millennium Development Goals five years later. http://www. bioversityinternational.org/uploads/tx_news/Agricultural_ biodiversity_and_elimination_of_hunger_and_poverty_1062. pdf (accessed January 2015).

3. Njomaha C (2004) Agricultural change, food production and sustainability in the far north of Cameroon. PhD Dissertation, Leiden University.

4. Arimond M, Wiesmann D, Becquey E et al. (2010) Simple food group diversity indicators predict micronutrient adequacy of women's diets in 5 diverse, resource-poor settings. J Nutr 140, 2059-2069.

5. Grivetti LE \& Ogle BM (2000) Value of traditional foods in meeting macro- and micronutrient needs: the wild plant connection. Nutr Res Rev 13, 31-46. 
6. Barucha Z \& Pretty J (2010) The roles of wild foods in agricultural systems. Philos Trans R Soc B 365, 2913-2926.

7. Kant AK (2004) Dietary patterns and health outcomes. J Am Diet Assoc 104, 615-635.

8. Savy M, Martin-Prevel Y, Traissac P et al. (2006) Dietary diversity scores and nutritional status of women change during the seasonal food shortage in rural Burkina Faso. J Nutr 136, 2625-2632.

9. Penafiel D, Lachat C, Espinel R et al. (2011) Systematic review on the contributions of edible plant and animal biodiversity to human diets. EcoHealth 8, 381-399.

10. Roche ML, Creed-Kanashiro HM, Tuesta I et al. (2008) Traditional food diversity predicts dietary quality for the Awajún in the Peruvian Amazon. Public Health Nutr 11, 457-465.

11. Legwaila GM, Mojeremane W, Madisa ME et al. (2011) Potential of traditional food plants in rural household food security in Botswana. J Hortic For 3, 171-177.

12. Termote C, Bwama Meyi M, Dhed'a et al. (2012) A biodiverse rich environment does not contribute to a better diet: a case study from DR Congo. PLOS ONE 7, e30533.

13. Nesamvuni C, Steyn NP \& Potgieter MJ (2001) Nutritional value of wild, leafy vegetables consumed by the VhaVhenda. S Afr J Sci 97, 51-54.

14. Kuhnlein H, Erasmus B \& Spigelski D (2009) Indigenous Peoples' Food Systems and Well-Being. Rome: FAO.

15. Fungo R, Muyonga J, Kaaya A et al. (2015) Nutrient quality and bioactive compounds of Baillonella toxisperma, Trichoschypa abut and Pentaclethra macrophylla from Cameroon. J Food Sci Nutr 3, 292-301.

16. Keller GB, Mndiga H \& Maass B (2006) Diversity and genetic erosion of traditional vegetables in Tanzania from the farmer's point of view. Plant Genet Resour 3 , 400-413.

17. Food and Agriculture Organization of the United Nations (2005) Building on Gender, Agrobiodiversity and Local Knowledge. A Training Manual. Rome: FAO.

18. Fungo R, Muyonga JH, Kabahenda M et al. (2016) Factors influencing consumption of nutrient rich forest foods in rural Cameroon. Appetite 97, 176-184.

19. Awono A, Djouguep A, Zapfack L et al. (2009) The potential of Irvingia gabonensis: can it contribute to the improvement of the livelihoods of producers in Southern Cameroon? Int J Soc For 2, 67-85.

20. International Food Policy Research Institute (2014) Global Nutrition Report 2014: Actions and Accountability to Accelerate the World's Progress on Nutrition. Washington, DC: IFPRI.

21. UNICEF (2015) Undernutrition contributes to half of all deaths in children under 5 and is widespread in Asia and Africa. http://data.unicef.org/nutrition/malnutrition\#sthash. fWmPHjYA.dpuf (accessed March 2015).

22. World Bank (2006) Repositioning Nutrition as Central to Development: A Strategy for Large-Scale Action. Washington, DC: World Bank; available at http://siteresources.worldbank. org/NUTRITION/Resources/281846-1131636806329/Nutrition Strategy.pdf

23. National Institute of Statistics \& ORC Macro International, Inc. (2001) Cameroon Demographic and Health Survey 2011. Cameroon and Calverton, MD: National Institute of Statistics and ORC Macro International, Inc.

24. Sneyd LQ (2013) Wild food, prices, diets and development: sustainability and food security in urban Cameroon. Sustainability 5, 4728.

25. Ahenkan A \& Boon E (2008) Impact of deforestation on medicinal plants in Ghana. http://www.grin.com/en/e-book/ 90577/impact-of-deforestation-on-medicinal-plants-in-ghana (accessed May 2016).

26. Figueroa BM, Tittonell P, Giller KE et al. (2009) The contribution of traditional vegetables to household food security in two communities of Vihiga and Migori Districts, Kenya. Acta Hort (ISHS) 806, 57-64.

27. United Nations Environment Programme (1999) Republic of Cameroon: Biodiversity Status Strategy and Action Plan; Convention on Biological Diversity. Yaoundé: Republic of Cameroon and UNEP.

28. Medinof (2004) Plan d'aménagement des concessions N81046/UFA10046 et N81059/UFA 10059 et 10060 (Management plans of concessions N81046/UFA10046 and N81059/UFA 10059 and 10060). Yaoundé: SCTB.

29. Enviro Consulting (2009) Étude d'impact environnemental des activités d'exploitation de la concession forestière n81050 (UFA 09017 and 09018) située dans les arrondissements d'Ebolowa II, Biwongbulu et de Mvangan département de Lamvila, région du sud (Environmental impact assessment of logging activities in concession n81050 (UFA 09017 and 09018) in the districts Ebolowa II, Biwongbulu and Mvangan, department of Lamvila, South Region). Yaoundé: FIPCAM.

30. Fisher LD (1998) Self-designing clinical trials. Stat Med 17, 1551-1562.

31. Chao S (2012) Forest Peoples: Numbers across the World. Moreton-in-Marsh: Forest Peoples Programme UK

32. Maundu PM (1996) Utilization and conservation status of wild food plants in Kenya. In The Biodiversity of African Plants. Proceedings of the XIV AETFAT Congress, 22-27 August 1994, Wageningen, The Netherlands, pp. 678-683 [LJG Van der Maesen, XM van der Burg and JM van Medenbach de Rooy JM, editors]. Dordrecht: Kluwer Academic Publishers.

33. Becquey E, Capon G \& Martin-Prével Y (2009) Validation of Dietary Diversity as a Measure of the Micronutrient Adequacy of Women's Diets: Results from Ouagadougou (Burkina Faso). Washington, DC: Food and Nutrition Technical Technical Assistance II Project (FANTA), FHI 360.

34. Ingram V \& Schure J (2010) Review of Non Timber Forest Products (NTFPS) in Central Africa: Cameroon. Yaoundé: CIFOR/FORENET Project.

35. Black AE (2000) Critical evaluation of energy intake using the Goldberg cutoff for energy intake:basal metabolic rate. A practical guide to its calculation, use and limitations. Int J Obes Relat Metab Disord 24, 1119-1130.

36. Mirmiran P, Azadbakht L, Esmaillzadeh A et al. (2004) Dietary diversity score in adolescents-a good indicator of the nutritional adequacy of diets: Tehran Lipid and Glucose Study. Asia Pac J Clin Nutr 13, 56-60.

37. Yamauchi T, Sato H \& Kawamura K (2000) Nutritional status, activity pattern, and Dietary intake among the Baka hunter-gatherers in the village camps in Cameroon. Afr Stud Monogr 21, 67-82.

38. Djoulde D, Essia-Ngang JJ \& Etoa FX (2012) Nutritional properties of 'bush meals' from north Cameroon's biodiversity. Adv Appl Sci Res 3, 1482-1493.

39. Kana Sop MM, Gouado I, Teugwa M et al. (2008) Mineral content in some Cameroonian household foods eaten in Douala. Afr J Biotechnol 7, 3085-3309.

40. Gibson RS \& Ferguson EL (1999) An Interactive 24-hour Recall for Assessing the Adequacy of Iron and Zinc Intakes in Developing Countries. Washington, DC: ILSI Press.

41. Food and Agriculture Organization of the United Nations (2011) Guidelines for Measuring Housebold and Individual Dietary Diversity. Rome: FAO.

42. Coates J, Swindale A \& Bilinsky P (2007) Household Food Insecurity Access Scale (HFIAS) for Measurement of Housebold Food Access: Indicator Guide (v. 3). Washington, DC: Food and Nutrition Technical Assistance Project, Academy for Educational Development.

43. Institute of Medicine (2005) Dietary Reference Intakes for Energy, Carbohydrate, Fiber, Fat, Fatty Acids, Cholesterol, 
Protein, and Amino Acids. Washington, DC: National Academies Press.

44. World Health Organization \& Food and Agriculture Organization of the United Nations (2004) Vitamin and Mineral Requirements in Human Nutrition. Geneva: WHO.

45. Stadlmayr B, Charrondiere UR, Addy P et al. (2010) Composition of Selected Foods from West Africa. Rome: FAO.

46. Vinceti B, Eyzaguirre P \& Johns T (2008) The nutritional role of forest plant foods for rural communities. In Human Health and Forests: A Global Overview of Issues, Practice and Policy, pp. 63-96 [CJP Colfer, editor]. London: Earthscan.

47. Food and Nutrition Board, Institute of Medicine (2001) Dietary Reference Intakes for Vitamin A, Vitamin K, Arsenic, Boron, Chromium, Copper, Iodine, Iron, Manganese, Molybdenum, Nickel, Silicon, Vanadium and Zinc. Washington, DC: National Academies Press.

48. Ejiofor MAN, Onwuboker SN \& Okafor JC (1987) Developing improved method of processing and utilization of kernel of Irvingia gabonensis. Int Tree Crops $J \mathbf{4}$, 283-290.

49. Black R (2003) Micronutrient deficiency - an underlying cause of morbidity and mortality. Bull World Health Organ 81, 79.

50. Kuhnlein H, Erasmus B, Creed-Kanashiro H et al. (2006) Indigenous peoples' food systems for health: finding interventions that work. Public Health Nutr 9, 1013-1019.

51. Hadjichambis AC, Paraskeva-Hadjichambi D, Della A et al. (2008) Wild and semi-domesticated food plant consumption in seven circum-Mediterranean areas. Int J Food Sci Nutr 59, $383-414$.

52. Mavengahama S, McLachan M \& de Clercq W (2013) The role of wild vegetable species in household food security in maize based subsistence cropping systems. Food Sec 5, 227-233.

53. Boedecker J, Termote C, Assogbadjo AC et al. (2014) Dietary contribution of wild edible plants to women's diets in the buffer zone around the Lama forest, Benin an underutilized potential. Food Sec 6, 833-849.

54. Johnson A \& Behrens CA (1982) Nutritional criteria in Machiguenga food production decisions: a linearprogramming analysis. Hum Ecol 10, 167-189.

55. Koppert GJA, Dounias E, Froment A et al. (1993) Food consumption in three forest populations of the southern coastal areas of Cameroon: Yassa - Mvae - Bakola. In Man and the Biosphere Series. vol. 13: Tropical Forests, People and Food: Biocultural Interactions and Applications to Development, pp. 295-310 [CM Hladik, A Hladik, OF Linares et al., editors]. Paris and Nashville, TN: UNESCO and Parthenon Publishing.
56. Keegan WF (1986) The optimal foraging analysis of horticultural production. Am Anthropol 88, 92-107.

57. Powell B, Maundu P, Kuhnlein H et al. (2013) Wild foods from farm and forest in the East Usambara Mountains, Tanzania. Ecol Food Nutr 52, 451-478.

58. Ogle BM, Hung P \& Tuyet H (2001) Significance of wild vegetables in micronutrient intakes of women in Vietnam: an analysis of food variety. Asia Pac J Clin Nutr 10, 21-30.

59. Hoddinott J \& Yohannes Y (2002) Dietary Diversity as a Household Food Security Indicator. Washington, DC: Food and Nutrition Technical Assistance Project, Academy for Educational Development.

60. Van Liere MJ, Ategbo EAD, Den Hartog AP et al. (1995) The consequences of seasonal food insecurity for individual food-consumption patterns in north-western Benin. Food Nutr Bull 16, 147-154.

61. Tarini A, Bakari S \& Delisle H (1999) The overall nutritional quality of the diet is reflected in the growth of Nigerian children. Sante 9, 23-31.

62. Sawadogo PS, Martin-Prevel Y, Savy M et al. (2006) An infant and child feeding index is associated with the nutritional status of 6- to 23-month-old children in rural Burkina Faso. J Nutr 136, 656-663.

63. Levang P, Lescuyer G, Dehu C et al. (2015) Does gathering really pay? Case studies from forest areas of the East and South regions of Cameroon. Forests Trees Livelihoods 24, 128-143.

64. Maisonneuve C, Sanou D, Ouattara K et al. (2014) Women's empowerment: a key mediating factor between cotton cropping and food insecurity in Western Burkina Faso. J Food Sec 2, 51-58.

65. Bailey RC \& Peacock NR (1988) Efe pygmies of northeast Zaire: subsistence strategies in the Ituri forest. In Coping with Uncertainty in Food Supply, pp. 88-117 [I de Garine and GA Harrison, editors]. Oxford: Clarendon Press.

66. Saaka M \& Osman SM (2013) Does household food insecurity affect the nutritional status of preschool children aged 6-36 months? Int J Popul Res 2013, 1-12.

67. Maxwell D, Vaitla B \& Coates J (2014) How do indicators of household food security measure up? An empirical comparison from Ethiopia. Food Policy 47, 107-116.

68. Ruel MT (2003) Operationalizing dietary diversity: a review of measurement issues and research priorities. J Nutr 133, 11 Suppl. 2, 3911S-3926S.

69. Getachew AG, Asfaw Z, Singh V et al. (2013) Dietary values of wild and semi-wild edible plants in Southern Ethiopia. Afr J Food Agric Nutr Dev 13, 7485-7503.

70. Hamawa Y (2013) Wild edible plants used by Guiziga people of far north region of Cameroon. Int J Med Arom Plants 3, 136-143. 